\title{
Interaction between Carbenicillin and $\beta$-Lactamases from Gram-negative Bacteria
}

\author{
By M. BOBROWSKI AND E. BOROWSKI \\ Department of Microbiology, University Medical School, Bialystok, Poland \\ and Department of Drug Technology and Biochemistry, \\ Technical University, Gdańsk, Poland
}

(Accepted for publication I6 July 197I)

\begin{abstract}
SUMMARY
The rates of hydrolysis of carbenicillin and of other penicillins and cephalosporins by nine different $\beta$-lactamase preparations obtained from Gram-negative bacteria were compared. Enzymes produced by Klebsiella strains, most active against penicillins, as well as $\beta$-lactamases synthesized by Escherichia coli and Proteus mirabilis strains hydrolysed carbenicillin, although at relatively lower rates than ampicillin or cephaloridine. In contrast, carbenicillin was extremely resistant to $\beta$-lactamases with a predominant cephalosporinase activity as produced by Pseudomonas aeruginosa, Proteus vulgaris and Enterobacter strains. The cephalosporin $\beta$-lactamases activity of these enzymes was inhibited by carbenicillin. A considerably increased enzymic activity observed in one strain of Pseudomonas aeruginosa when grown in the presence of carbenicillin or other $\beta$-lactam antibiotics was unable to destroy carbenicillin to any measurable extent. A possible permeability barrier to carbenicillin has been demonstrated in some strains.
\end{abstract}

\section{INTRODUCTION}

Carbenicillin, an $\alpha$-carboxybenzylpenicillin, has been shown to be effective in the treatment of infections caused by Gram-negative bacteria and those due to Pseudomonas aeruginosa in particular (e.g. Brumfitt, Percival \& Leight, I967; Stratford, I968; Malmborg, I969; Bodey, Rodriguez \& Luce, 1969). Although variation in sensitivity of the antibiotic to hydrolysis by $\beta$-lactamases of different strains of enteric bacteria has been described (Acred, Brown, Knudsen, Rolinson \& Sutherland, I967; Brumfitt et al. I967; Rolinson \& Sutherland, I968; Neu \& Swarz, I 969) and some quantitative data have been reported on this activity in several carbenicillin-resistant strains (Nishida, Yokota \& Matsubara, 1969; Newsom, Sykes \& Richmond, I970; Sykes \& Richmond, I970; Fullbrook, Elson \& Slocombe, 1970) no attempts have been made to explain the occurrence of many carbenicillinsensitive strains known to produce active $\beta$-lactamase. The action of several distinct $\beta$ lactamases from Gram-negative bacilli on carbenicillin, and the action of carbenicillin on these enzymes is reported here.

\section{METHODS}

Organisms. Strains of Escherichia coli, Klebsiella spp., Enterobacter sp., Proteus mirabilis, Proteus vulgaris and Pseudomonas aeruginosa isolated from clinical sources were selected as representative of over 300 strains screened for $\beta$-lactamase activity. Additionally, the Escherichia coli $\mathrm{K}$ I 2 culture which acquired the R-factor from Salmonella enteritidis donor strain by conjugation was included in the experiments. 
Materials. Carbenicillin, ampicillin, methicillin were supplied by Beecham Research Laboratories, Betchworth, Surrey; benzylpenicillin, cloxacillin, phenoxymethylpenicillin and 6-aminopenicillanic acid (6-APA) by Polish Pharmaceutical Industry 'Polfa', Warsaw, Poland; cephalothin by Eli Lilly Co., Indianapolis, Indiana, U.S.A. and cephaloridine by Glaxo Laboratories Ltd, Greenford, Middlesex.

The Bacillus cereus $\beta$-lactamase preparation 'Neutrapen' was a product of Riker Laboratories, Northridge, California, U.S.A. Three partially purified staphylococcal $\beta$-lactamases were kindly supplied by Dr M. Goldner, University of Toronto, Canada.

Culture media. In most experiments nutrient broth was used. Some strains were grown in CY medium (Novick, 1963). The Proteus vulgaris and Pseudomonas aeruginosa strains which had very low $\beta$-lactamase activity were cultured in the presence of $500 \mu \mathrm{g}$. benzylpenicillin/ $\mathrm{ml}$. as inducing agent.

Preparation of cell-free $\beta$-lactamases. Batches of 51 . culture grown with shaking at $37^{\circ}$ for $6 \mathrm{~h}$. were centrifuged, the deposit washed twice with saline and resuspended in $\mathrm{O} \cdot \mathrm{I} \mathrm{M}$ phosphate buffer, $\mathrm{pH} 7 \cdot 0$, to a concentration of 50 to $100 \mathrm{mg}$. dry wt $/ \mathrm{ml}$. The suspensions were then treated in an MSE 100 ultrasonic disintegrator for 2.5 to $3.5 \mathrm{~min}$. in $10 \mathrm{ml}$. portions, centrifuged at $5000 \mathrm{~g}$ for $20 \mathrm{~min}$. to remove whole organisms and then at $20,000 \mathrm{~g}$ for $30 \mathrm{~min}$. in a refrigerated centrifuge. The clear supernatant solutions were dialysed three times, each for $8 \mathrm{~h}$. at $4^{\circ}$ against I mM-phosphate buffer, $\mathrm{pH} \mathrm{7} \cdot 0$, centrifuged again at $20,000 \mathrm{~g}$ for $30 \mathrm{~min}$. at $4^{\circ}$ and lyophilysed. The protein content in the preparations was estimated (Lowry, Rosebrough, Farr \& Randall, I95I) with bovine serum albumin as standard.

Induction of $\beta$-lactamase formation. Six $250 \mathrm{ml}$. flasks containing $50 \mathrm{ml}$. of CY medium, each inoculated with $5 \mathrm{ml}$. of $\mathrm{I} 8 \mathrm{~h}$. broth culture of Pseudomonas aeruginosa 6604 were shaken at $37^{\circ}$. After $2 \mathrm{~h}$. incubation one antibiotic (benzylpenicillin, ampicillin, methicillin, cephaloridine, $500 \mu \mathrm{g}$. $/ \mathrm{ml}$., or carbenicillin, $250 \mu \mathrm{g} . / \mathrm{ml}$.) was added to each of five flasks which were incubated for a further $6 \mathrm{~h}$. The resulting bacterial growth was collected by centrifugation and treated as described in the previous section.

Assays of $\beta$-lactamase activity. Rates of hydrolysis of penicillins and cephalosporins were measured using the hydroxylamine method of Boxer \& Everett (1949) slightly modified. In this assay, $0.5 \mathrm{ml}$. of the substrate solution, IO $\mathrm{mm}$, in $0.0 \mathrm{I} \mathrm{M-phosphate} \mathrm{buffer,} \mathrm{pH} 7.0$, was added to $0.5 \mathrm{ml}$. of diluted enzyme preparation, mixed and incubated at $30^{\circ}$ in a water bath for $\mathrm{I} h$. After addition of hydroxylamine reagent and a solution of ferric ions the extinction at $515 \mathrm{~nm}$. was determined in a Carl-Zeiss 'Spekol' spectrocolorimeter against a suitable blank. Appropriate controls omitting substrate or enzyme were included.

In some experiments the $\beta$-lactamase activity of suspensions of whole organisms was determined by a similar method described by Borowski, Dzierżanowska \& Bobrowski (I968).

For kinetics experiments, mainly with $\beta$-lactamase produced by Pseudomonas aeruginosa 28, the acidimetric indicator method of Hamilton-Miller, Smith \& Knox (I963) was employed. For determination of Michaelis constants the reaction mixture consisted of $\mathrm{I} \mathrm{ml}$. of enzyme solution in $5 \mathrm{~mm}$-phosphate buffer, $\mathrm{pH} 7.0, \mathrm{I} \mathrm{ml}$. of cephaloridine solution in the same buffer in concentrations ranging from $0 . \mathrm{I}$ to Io $\mathrm{mM}, \mathrm{I} \cdot 6 \mathrm{ml}$. of $0.0 \mathrm{I} \%$ bromothymol blue solution and $5 \mathrm{~mm}$-phosphate buffer added to give a final volume of $6 \mathrm{ml}$. For enzyme inhibition measurements the reaction was carried out in the presence of a fixed initial concentration of cephaloridine equal to $2 \mathrm{~mm}$ and various amounts of inhibitor between 10 and $200 \mu \mathrm{M}$ for carbenicillin, 2.5 and $100 \mu \mathrm{M}$ for methicillin and from 0.25 to $5 \mu \mathrm{M}$ for cloxacillin. The rates of enzymatic hydrolysis of cephaloridine were determined spectrophotometrically at $6 \mathrm{I} 5 \mathrm{~nm}$. and the velocities of reaction $(V)$ were calculated from the progress curves. 
The Michaelis constant $\left(K_{\mathrm{m}}\right)$ was calculated from a graph constructed from $V / S$ values versus substrate concentration $(S)$. The quotients $K_{\mathrm{i}} / K_{\mathrm{m}}$ were obtained from data plotted in the manner described by Hamilton-Miller (1966) and the dissociation constants of enzymeinhibitor complex $\left(K_{\mathrm{i}}\right)$ were calculated knowing the respective values of $K_{\mathrm{m}}$ and $K_{\mathrm{i}} / K_{\mathrm{m}}$.

The activity of the enzyme was expressed as units $/ \mathrm{mg}$. protein or units $/ \mathrm{mg}$. of dry weight according to Pollock \& Torriani ( I953); I unit is equivalent to I $\mu$ mole of substrate hydrolysed/I h. at $30^{\circ}, \mathrm{pH} 7 \cdot 0$.

Paper and thin-layer chromatography. Paper chromatography on Whatman no. I paper was carried out using an ascending technique in $n$-butanol + pyridine + water (I:I:I);nbutanol + acetic acid + water $(4: 1: 5) ; n$-butanol + ethanol + water $(4: 1: 5)$ and $n$-propanol + water $(7: 3)$ solvent systems. Thin-layer chromatography was performed on Kiesielgel $G$ in the three latter systems.

The $\beta$-lactamase preparations were incubated at room temperature for I to $4 \mathrm{~h}$. with $20 \mathrm{mg}$. of either benzylpenicillin or carbenicillin/ml., and then applied to the paper or thin layer. Benzylpenicillin, carbenicillin, 6-APA and their corresponding penicilloic acids were used as markers. After development spots were located by spraying the chromatograms with sodium hydroxide solution and iodine-starch reagent or with the iodine-starch reagent only (Sneath \& Collins, I96I).

\section{RESULTS}

The activity of $\beta$-lactamase preparations against carbenicillin and other $\beta$-lactam antibiotics. Results obtained for the activities of $\beta$-lactamase preparations against carbenicillin, benzylpenicillin, phenoxymethylpenicillin, ampicillin, cephalothin and cephaloridine are presented in Table I. Comparative figures for the $\beta$-lactamases formed by three staphylococcal strains and the strain of Bacillus cereus are given in Table 2.

Three conclusions may be drawn when these substrate profiles are considered. First, the four $\beta$-lactamases which hydrolysed cephalosporin derivatives much more rapidly than penicillins and thus which may be regarded as typical cephalosporinases showed very little, if any, ability to split carbenicillin. Secondly, the relative rates of carbenicillin hydrolysis were a little higher for the $\beta$-lactamases produced by the two Klebsiella strains than for the enzymes formed by Proteus mirabilis and Escherichia coli strains including that $\beta$-lactamase

Table I. Substrate profiles of $\beta$-lactamase preparations examined

\begin{tabular}{|c|c|c|c|c|c|c|}
\hline \multirow[b]{2}{*}{ Organism } & \multirow[b]{2}{*}{$\begin{array}{l}\text { Specific } \\
\text { activity* }\end{array}$} & \multicolumn{5}{|c|}{$\begin{array}{l}\text { Relative rates of hydrolysis, } \\
\text { taking the rate for benzylpenicillin as } 100\end{array}$} \\
\hline & & $\begin{array}{l}\text { Carbeni- } \\
\text { cillin }\end{array}$ & Ampicillin & $\begin{array}{l}\text { Phenoxy- } \\
\text { methyl- } \\
\text { penicillin }\end{array}$ & $\begin{array}{l}\text { Cephalori- } \\
\text { dine }\end{array}$ & Cephalothin \\
\hline Pseudomonas aeruginosa $28^{+}$ & I 5 & - & 5 & 52 & 290 & 140 \\
\hline Pseudomonas aeruginosa $6604^{+}$ & 3 & - & - & nd & 440 & nd \\
\hline Enterobacter sp. I $83 z$ & $4 \cdot 5$ & - & $\mathrm{I} 8 \cdot 5$ & 95 & 1050 & 290 \\
\hline Proteus vulgaris $\mathrm{I} \mathrm{IOZ}$ & 10.5 & 3 & $31 \cdot 5$ & nd & 4200 & 3080 \\
\hline Klebsiella pneumoniae 23 & $3 \cdot 5$ & 20 & I 3 I & I I 5 & 28 & - \\
\hline Klebsiella sp. $3^{8}$ & $26 \cdot 5$ & $13 \cdot 5$ & I 39 & IIO & 36 & $7 \cdot 5$ \\
\hline Escherichia coli I Iz & 28 & IO & 95 & 63.5 & 75 & 10 \\
\hline Proteus mirabilis $\mathrm{I} \mathrm{I} 8 \mathrm{z}$ & 300 & 12 & 89 & 58 & 56 & 10 \\
\hline Escherichia coli $\mathrm{K} 12 \mathrm{R} \div(\mathrm{I} 7 / 9)$ & I I 5 & $10 \cdot 5$ & 84 & 67.5 & 78 & 8 \\
\hline
\end{tabular}

* $=\beta$-Lactamase units/mg. protein: benzylpenicillin as substrate; $-=$ activity too low to be determined accurately; $+=$ cultures induced with benzylpenicillin $(500 \mu \mathrm{g} . / \mathrm{ml}.) ; \mathrm{nd}=$ not determined. 
whose synthesis was mediated by an R-factor in E. coli $\mathrm{K} 12$. However, the absolute activity of two of these three latter strains against carbenicillin was apparently higher than of those two former. Thirdly, in every case carbenicillin was hydrolysed much more slowly than was ampicillin or cephaloridine.

A comparison of the relative rates of hydrolysis of carbenicillin by $\beta$-lactamases from Gram-positive and Gram-negative bacteria indicates that this antibiotic seems to be a more suitable substrate for staphylococcal or Bacillus cereus enzymes than for those produced by enteric bacilli.

The ability, or lack of ability, of some strains to produce carbenicillin-splitting enzymes was confirmed by chromatographic techniques. The approximate $R_{\mathrm{f}}$ values of $\alpha$-carboxybenzylpenicilloic acid, a product of enzymic hydrolysis of carbenicillin, were as follows: 0.32 - in $n$-butanol + pyridine + water (I:I:I); 0.57 - in $n$-butanol + acetic acid + water (4:I:5); 0.08 - in $n$-butanol +ethanol + water $(4: 1: 5)$ and 0.29 -in $n$-propanol + water $(7: 3)$ solvent systems. The corresponding values for carbenicillin were: $0.59 ; 0.87 ; 0.17$ and 0.39 , respectively.

Table 2. The rates of hydrolysis of carbenicillin as compared with those of benzylpenicillin by $\beta$-lactamase preparations from Gram-positive bacteria

\begin{tabular}{|c|c|c|c|}
\hline \multirow[b]{2}{*}{ Species } & \multirow[b]{2}{*}{ Strain } & \multicolumn{2}{|c|}{ Rates of hydrolysis (units/mg.) } \\
\hline & & Benzylpenicillin & Carbenicillin \\
\hline Staphylococcus aureus & 755 & $6.5(100)^{*}$ & $4 \cdot 4(68)$ \\
\hline S. aureus & 1422 & $12 \cdot 3(100)$ & $7 \cdot 0(57)$ \\
\hline S. aureus & HSC II & $13 \cdot 8(100)$ & $7 \cdot 5(54)$ \\
\hline Bacillus cereus & + & $+(100)$ & $+(30)$ \\
\hline
\end{tabular}

Table 3. Permeability factor values* for three $\beta$-lactam antibiotics

\begin{tabular}{|c|c|c|c|}
\hline Organism & $\begin{array}{c}\text { Benzyl- } \\
\text { penicillin }\end{array}$ & Carbenicillin & Cephaloridine \\
\hline Escherichia coli I Iz & 10 & 7 & $\mathbf{I}$ \\
\hline E. coli $66 \mathrm{E}$ & 5 & 7 & $\mathbf{I}$ \\
\hline E. coli $46 \mathrm{E}$ & 13 & 27 & $I$ \\
\hline E. coli $\mathrm{K} 12 \mathrm{R}^{+} \mathrm{I} 7$ & 17 & 3 & I \\
\hline E. coli $\mathrm{K} \mathrm{I} 2 \mathrm{R}^{+} \mathrm{I} 6$ & 54 & 9 & I \\
\hline Klebsiella sp. 38 & 9 & 8 & I \\
\hline Proteus mirabilis $\mathrm{I} \mathbf{1 8 \mathrm { z }}$ & 12 & 3 & $\mathbf{I}$ \\
\hline$P$. mirabilis $\mathrm{r} 39 \mathrm{z}$ & 9 & 5 & $\mathbf{I}$ \\
\hline
\end{tabular}

* = Ratio of $\beta$-lactamase activity of sonically treated to intact cell suspension; bènzylpenicillin, carbenicillin and cephaloridine as substrate.

As there were no traces of spots corresponding to 6-APA or desacyl-6-aminopenicilloic acid none of the strains tested produced penicillin amidase.

Permeability barrier to carbenicillin. The determination of $\beta$-lactamase activity against carbenicillin using suspensions of whole organisms and cell-free extracts from the same batch of culture made it possible to establish the presence of a permeability barrier between enzyme and its substrate and to estimate the intrinsic resistance to carbenicillin in some strains. The values of so-called permeability factors which may be regarded to a certain extent as measures of the intrinsic resistance of the cell are presented in Table 3. For comparison the figures calculated for benzylpenicillin and cephaloridine are also given. 


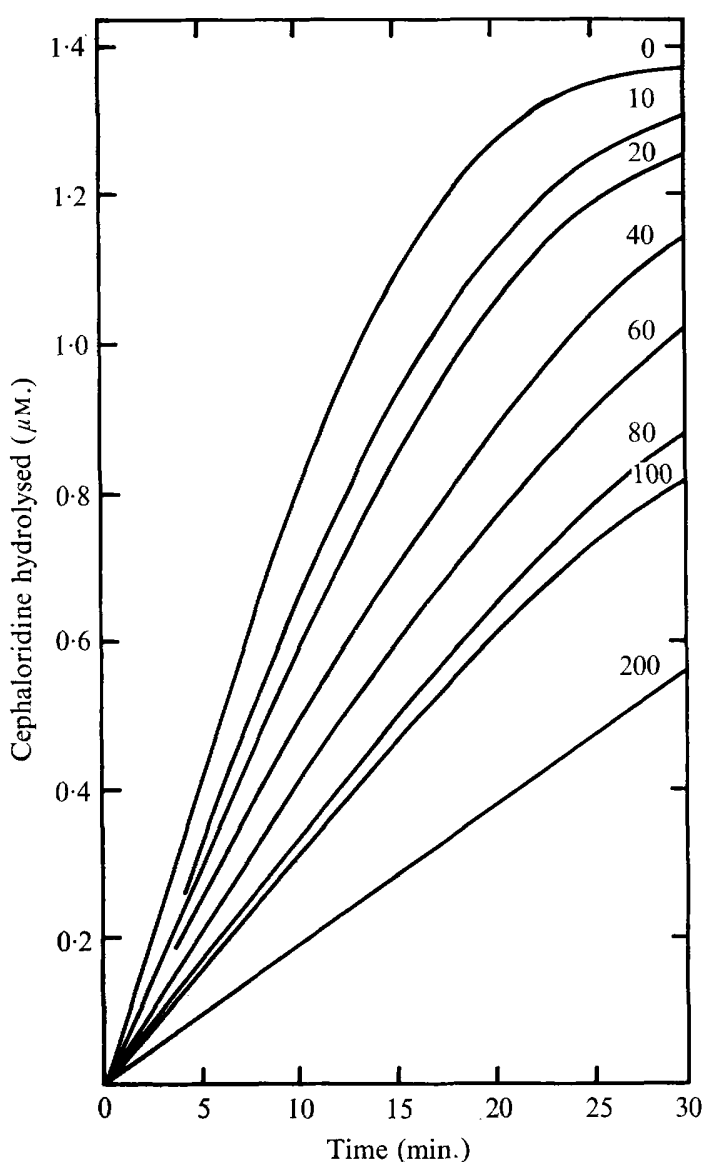

Fig. I. The effect of carbenicillin on the rate of the enzymatic cleavage of cephaloridine by $\beta$ lactamase from Pseudomonas aeruginosa 28 . The figures represent the concentrations of carbenicillin solutions expressed in $\mu \mathrm{M}$, added to $2 \mathrm{~mm}$-cephaloridine solution. Enzyme concentration: about 3 units/ml. Indicator acidimetric method.

Table 4. Effect of various inducers on activity of $\beta$-lactamase preparations obtained from Pseudomonas aeruginosa 6604

$\begin{array}{lccc}\text { Inducer } & \begin{array}{c}\text { Concentration } \\ \text { of inducer } \\ (\mu \mathrm{g} . / \mathrm{ml})\end{array} & \begin{array}{c}\text { Absolute } \\ \beta \text {-lactamase } \\ \text { activity* }\end{array} & \begin{array}{c}\text { Inducibility } \\ \text { coefficient } \\ \text { value } \dagger\end{array} \\ \text { None } & - & 0 \cdot 13 & \mathrm{I} \cdot 0 \\ \text { Benzylpenicillin } & 500 & 2 \cdot 16 & \mathrm{I} \cdot 6 \cdot 6 \\ \text { Ampicillin } & 500 & 2 \cdot 33 & \mathrm{I} 8 \cdot 0 \\ \text { Carbenicillin } & 250 & 0 \cdot 8 \mathrm{I} & 6 \cdot 2 \\ \text { Methicillin } & 500 & 0.23 & \mathrm{I} \cdot 8 \\ \text { Cephaloridine } & 500 & 4 \cdot 50 & 34.6\end{array}$

* = Units/mg. of dry bacterial weight: benzylpenicillin as substrate.

$\uparrow=$ Ratio of rate of induced enzyme formation to uninduced rate. 
Induction of $\beta$-lactamase activity by carbenicillin. Preliminary experiments established that the activity of both Pseudomonas aeruginosa strains tested was extremely low unless the culture was grown in the presence of benzylpenicillin. Other $\beta$-lactam antibiotics including carbenicillin were examined as enzyme inducers and Table 4 shows the $\beta$-lactamase activity of $P$. aeruginosa strain 6604 against benzylpenicillin after growth in the presence of these substances. It must be emphasized, however, that despite a great increase in $\beta$-lactamase activity, the activity against carbenicillin was still very low.

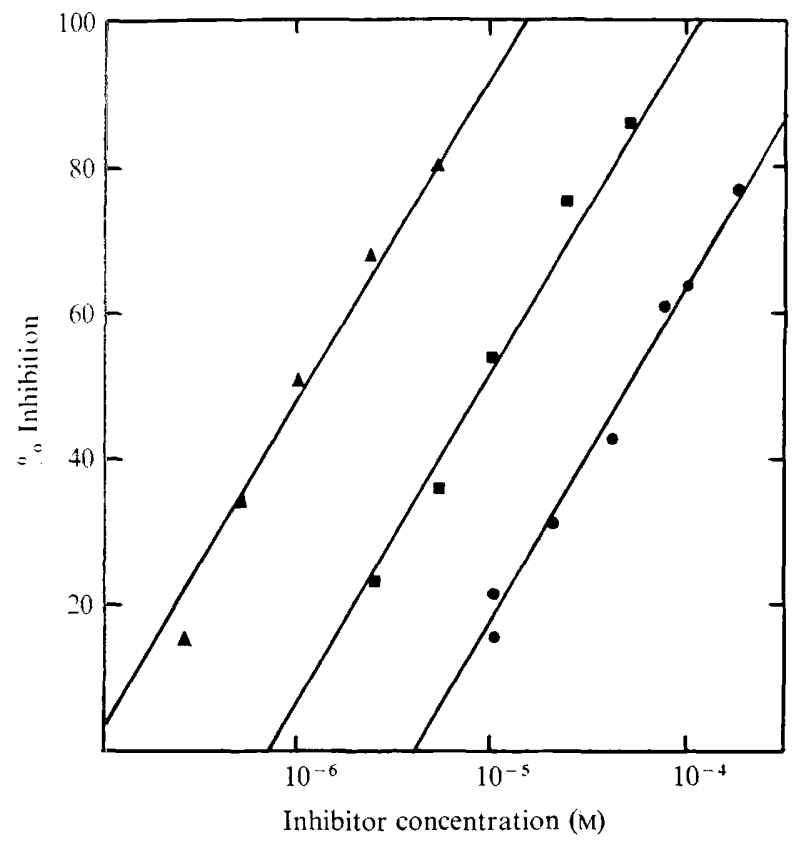

Fig. 2. Inhibitory effect of carbenicillin $(\boldsymbol{\bullet})$, cloxacillin $(\boldsymbol{\Delta})$ and methicillin $(\boldsymbol{\square})$ at various concentration on the rate of cephaloridine hydrolysis by Pseudomonas aeruginosa cephalosporin $\beta$-lactamase. Substrate concentration - $2 \mathrm{~mm}$; enzyme concentration - about 3 units/ml. Indicator acidimetric method.

Inhibition of cephalosporin $\beta$-lactamase activity. As carbenicillin was not hydrolysed by typical enzymes with a predominant cephalosporinase activity it was thought that this antibiotic might act as a competitive inhibitor of the cephalosporin $\beta$-lactamases.

The rates of hydrolysis of cephaloridine by $\beta$-lactamase preparation from Pseudomonas aeruginosa 28 in the presence of various concentrations of carbenicillin were compared with the rate of hydrolysis without carbenicillin. The results of this experiment (Fig. I) show that carbenicillin is an effective inhibitor of the hydrolysis of cephaloridine by pseudomonal $\beta$-lactamase. A comparison of the effectiveness of carbenicillin with that of cloxacillin and methicillin as enzyme inhibitors is given in Fig. 2. It can be seen that carbenicillin was a less powerful inhibitor than these two penicillins.

The affinity of cephaloridine for the $\beta$-lactamase produced by Pseudomonas aeruginosa 28 was low, the $K_{\mathrm{m}}$ value calculated from the data obtained being $4 \times 10^{-4} \mathrm{M}$. The kinetics constants calculated for carbenicillin, methicillin and cloxacillin expressed as $K_{\mathrm{i}}$ values were: $8 \cdot 4 \times \mathrm{IO}^{-6} ; \mathrm{I} \cdot 5 \times \mathrm{IO}^{-6}$ and $\mathrm{I} \cdot 8 \times \mathrm{IO}^{-7} \mathrm{M}$, respectively.

Preincubation of carbenicillin with $\beta$-lactamase from Pseudomonas aeruginosa 28 had no 
additional effect on the rate of cephaloridine degradation. This fact indicates that although carbenicillin may be firmly bound to the enzyme and blocks its active centre, the antibiotic produces very little, if any, conformative changes in the enzyme structure.

Results very similar to those with pseudomonal $\beta$-lactamase were obtained with cephalosporin $\beta$-lactamase from Enterobacter strain I $83 \mathrm{z}$; the affinity of carbenicillin for the active centre of this enzyme seems to be even greater, as the approximate concentration of carbenicillin required to produce $50 \%$ inhibition of the $\beta$-lactamase was of the order of $10^{-7} \mathrm{M}$.

It seemed possible that synergy might be expected if carbenicillin were used with cephaloridine against some $\beta$-lactamase-producing organisms. However, preliminary experiments in vitro showed no potentiation between cephaloridine and carbenicillin.

\section{DISCUSSION}

On the basis of the results reported here the $\beta$-lactamases examined could be divided into three distinct groups according to their effect upon carbenicillin, other penicillins and cephalosporins.

The first group produced by Pseudomonas aeruginosa, Enterobacter and Proteus vulgaris strains consists of $\beta$-lactamases with preferential activity towards cephalosporins which caused very little or no inactivation of carbenicillin. The second group comprises $\beta$-lactamases with predominant penicillinase activity derived from klebsiellas which were able to hydrolyse carbenicillin to some measurable extent and demonstrated high relative rates of hydrolysis of ampicillin and phenoxymethylpenicillin. The third group synthesized by Proteus mirabilis and Escherichia coli strains contains broad-spectrum $\beta$-lactamases with mixed penicillinase-cephalosporinase activity which destroyed carbenicillin at a considerable rate, although not so rapidly as other substrates.

This classification agrees in essential but not in details with the general classification of $\beta$-lactamases from Gram-negative bacteria proposed by some authors (Smith \& HamiltonMiller, I963; Ayliffe, I965; Citri \& Pollock, I966; Sawai, Mitsuhashi \& Yamagishi, I968; Smith, Hamilton-Miller \& Knox, 1969; Jack \& Richmond, 1970).

From the reports of earlier works on the antibacterial spectrum of carbenicillin (Acred et al. 1967; Brumfitt et al. 1967; Bodey \& Terrell, 1968; Rolinson \& Sutherland, 1968) it was known that most strains of Pseudomonas aeruginosa, Enterobacter and indole-positive Proteus are susceptible to carbenicillin, while the majority of strains of Klebsiella and Proteus mirabilis and some Escherichia coli strains appeared to be resistant. Those former species produce the $\beta$-lactamases classified here as falling into the first group and the latter synthesize enzymes classified as falling into the second and third groups. This suggests that the sensitivity of Gram-negative bacteria to carbenicillin depends primarily on the type of $\beta$-lactamase produced by these organisms.

Special attention should be paid to the strains of Gram-negative bacilli possessing an extrachromosomal $\beta$-lactamase gene(s) which can be transferred from one species to another. It has been observed by Medeiros \& O'Brien (1968) as well as by Neu \& Swarz (1969) that such strains are highly resistant to carbenicillin. The data presented here confirm these observations as the R-factor-associated $\beta$-lactamase synthesized by Escherichia coli $\mathrm{K} I 2 \mathrm{R}^{+}$ (I 7/9) strain was able to hydrolyse carbenicillin at a considerable rate. Also two Pseudomonas aeruginosa strains extremely resistant to carbenicillin isolated by Lowbury et al. (1969) have been found to possess the R-factor-mediated $\beta$-lactamase in independent studies by Sykes \& Richmond (1970) and by Fullbrook, Elson \& Slocombe (1970).

The finding that $\beta$-lactamase activity against carbenicillin in some highly resistant strains 
was much greater after sonic treatment than the activity of intact cell suspension reveals that the access of the antibiotic into the cell is restricted. It must be assumed that this accessibility barrier may be responsible, at least in part, for bacterial resistance to carbenicillin in addition to $\beta$-lactamase activity. There are some good reasons to suspect that a mechanism of resistance associated with restricted permeability of the cell surface layers to carbenicillin molecules exists also, as a sole mechanism, in moderately resistant strains which form $\beta$-lactamases unable to hydrolyse the antibiotic. One such Pseudomonas aeruginosa strain resistant up to $800 \mu \mathrm{g}$. carbenicillin $/ \mathrm{ml}$. has been described in our previous work (Bobrowski, Dzierżanowska, Chamienia \& Borowski, 1970).

Sabath, Jago \& Abraham (I965) working on pseudomonal $\beta$-lactamase have reported that this enzyme is inducible. Similarly it has been established that the indole-positive Proteus as well as Enterobacter strains produce inducible $\beta$-lactamases (Hamilton-Miller, 1963; Ayliffe, 1963, 1965; Hennessey, 1967). All these authors have also observed that various antibiotics differ in their effectiveness as inducers of $\beta$-lactamase activity. In the present study it was found that carbenicillin was able to induce $\beta$-lactamase activity in one strain of Pseudomonas aeruginosa, although to relatively less extent than other antibiotics except methicillin. It should be noted, however, that the carbenicillin concentration in induced culture was only half the concentration of the other inducers.

It follows from the numerous reports that typical $\beta$-lactamases with a predominant cephalosporinase activity are strongly inhibited by penicillins, in particular by methicillin and cloxacillin (Hamilton-Miller \& Smith, 1964; Hamilton-Miller, Smith \& Knox, I965; Sabath et al. 1965; O'Callaghan \& Muggelton, 1967; Fleming, Goldner \& Glass, 1969). In view of the results reported here carbenicillin may be regarded as a very powerful inhibitor of cephalosporin $\beta$-lactamase, although less potent than methicillin or cloxacillin. All these three antibiotics were characterized by very low $K_{\mathrm{i}}$ values, showing a great affinity for the $\beta$-lactamase produced by Pseudomonas aeruginosa 28. An accurate determination of the kinetics constants of the enzyme for benzylpenicillin and ampicillin has not been made in this study but there are some indications that these antibiotics have a lower affinity for the active centre than has carbenicillin.

Despite the promising findings from experiments performed with cell-free preparations the inhibitory effect of carbenicillin on cephaloridine inactivation has not been seen when an intact cell system was employed. This possibly can be attributed to different ability of these two antibiotics to reach the inside of the cell. Cephaloridine penetrates through surface layers of the cell very freely, while, on the contrary, carbenicillin meets some permeability barrier; therefore, it is possible that cephaloridine had been hydrolysed inside the cell envelope by the time carbenicillin reached a sufficient protective concentration. If the hypothesis postulated above were true one more requirement for $\beta$-lactam antibiotics synergy should be added to those conditions formulated by Sabath (I968).

The authors are indebted to Beecham Research Laboratories and to Polish Pharmaceutical Industry 'Polfa' for generous gift of penicillins. Sincere thanks are due to Dr M. Goldner for supplying staphylococcal $\beta$-lactamase preparations and to Professor Jerzy Borowski for his helpful discussions and criticism. 


\section{REFERENCES}

Acred, P., Brown, D. M., Knudsen, E. T., Rolinson, G. N. \& Sutherland, R. (1967). New semisynthetic penicillin active against Pseudomonas pyocyanea. Nature, London 215, 25-30.

AYLIFFE, G. A. J. (1963). Ampicillin inactivation and sensitivity of coliform bacilli. Journal of General Microbiology 30, 339-348.

AyLIFFE, G. A. J. (I965). Cephalosporinase and penicillinase activity of Gram-negative bacteria. Journal of General Microbiology 40, 119-126.

Bobrowski, M., Dzierżanowska, D., Chamienia, N. \& Borowski, J. (1970). Activity of $\alpha$-carboxybenzylpenicillin and gentamycin against Pseudomonas aeruginosa bacilli. (In Polish.) Polski Tygodnik Lekarski 25, $1285-1287$

Bodey, G. P., Rodriguez, V. \& LuCE, J. K. (1969). Carbenicillin therapy of Gram-negative bacilli infections. The American Journal of Medical Sciences 257, 408-414.

BODEY, G. P. \& TERRELL, L. M. (I968). In vitro activity of carbenicillin against Gram-negative bacilli. Journal of Bacteriology 95, I 587-I 590.

Borowski, J., Dzierżanowska, D. \& Bobrowski, M. (1968). Mechanisms of resistance of Klebsiella strains to the antibiotics of penicillin and cephalosporin groups. Archivum Immunologiae et Therapiae Experimentalis 16, 209-218.

BoXer, G. E. \& Everett, P. M. (1949). Colorimetric determination of benzyl penicillin. Analytical Chemistry 2I, 670-673.

Brumfitt, W., Percival, A. \& Leight, D. A. (1967). Clinical and laboratory studies with carbenicillin, a new penicillin active against Pseudomonas pyocyanea. Lancet I, 1289-1293.

Citri, N. \& Pollock, M. R. (1966). The biochemistry and function of $\beta$-lactamase (penicillinase). Advances in Enzymology 28, 237-323.

Fleming, P. C., GoldneR, M. \& Glass, D. G. (1969). Inhibition of Aerobacter cephalosporin $\beta$-lactamase by penicillins. Journal of Bacteriology 98, 394-397.

Fullbrook, P. D., Elson, S. W. \& Slocombe, B. (1970). R-factor-mediated $\beta$-lactamase in Pseudomonas aeruginosa. Nature, London 226, 1054-1056.

Hamilton-Miller, J. M. T. (1963). Inducible penicillinase in Proteus morganii. Biochemical and Biophysical Research Communications 13, 43-48.

Hamilton-Miller, J. M. T. (1966). A novel method for evaluating $K_{\mathrm{i}} / K_{\mathrm{m}}$ and its application to the competitive inhibition of staphylococcal penicillinase by cephalosporins. Biochemical Journal Ior, $40 \mathrm{C}-4 \mathbf{2} \mathrm{C}$.

Hamilton-Miller, J. M. T. \& Smith, J. T. (1964). Inhibition of penicillinases from Gram-positive and Gram-negative bacteria by substrate analogues. Nature, London 201, 999-1001.

Hamilton-Miller, J. M. T., Smith, J. T. \& KnOx, R. (I963). The estimation of penicillins and penicillin destruction. Journal of Pharmacy and Pharmacology 15, 8I-91.

Hamilton-MilleR, J. M. T., Smith, J. T. \& KNox, R. (1965). Interaction of cephaloridine with penicillinaseproducing Gram-negative bacteria. Nature, London 208, 235-237.

Hennessey, T. D. (1967). Inducible $\beta$-lactamase in Enterobacter. Journal of General Microbiology 49, 277285.

JACK, G. W. \& Richmond, M. H. (1970). A comparative study of eight distinct $\beta$-lactamases synthesized by Gram-negative bacteria. Journal of General Microbiology 6r, 43-6r.

Lowbury, E. J. L., Kidson, A., Lilly, H. A., Ayliffe, G. A. J. \& Jones, R. J. (I969). Sensitivity of Pseudomonas aeruginosa to antibiotics; emergence of strains highly resistant to carbenicillin. Lancet 2 , 448-452.

Lowry, O. H., Rosebrough, N. J., Farr, A. L. \& Randall, R. J. (I951). Protein measurement with the Folin phenol reagent. Journal of Biological Chemistry I93, 265-275.

Malmborg, A. S. (1969). Clinical evaluation of carbenicillin in Pseudomonas infection of the urinary tract. Scandinavian Journal of Urology and Nephrology 3, 45-49.

Medeiros, A. A. \& O'Brien, T. F. (I968). R-factor-mediated increments in levels of resistance to and enzymatic degradation of penicillins and cephalosporins. Antimicrobial Agents and Chemotherapy-1967, $271-278$.

Neu, H. C. \& Swarz, H. (1969). Resistance of Escherichia coli and Salmonella typhimurium to carbenicillin. Journal of General Microbiology 58, 30I-305.

Newsom, S. W. B., Sykes, R. B. \& Richmond, M. H. (1970). Detection of a $\beta$-lactamase markedly active against carbenicillin in a strain of Pseudomonas aeruginosa. Journal of Bacteriology ror, 1079-1080. 
Nishida, M., Yokota, Y. \& Matsubara, T. (1969). Studies on microbial degradation of carbenicillin. Journal of Antibiotics 22, 381-383.

Novick, R. P. (1963). Analysis by transduction of mutations affecting the penicillinase formation in Staphylococcus aureus. Journal of General Microbiology 33, I $2 \mathrm{I}-136$.

O'Callaghan, C. H. \& Muggleton, P. W. (1967). The action of cephaloridine with cloxacillin or methicillin against $\beta$-lactamase-producing Gram-negative bacteria. Journal of General Microbiology 48, 449460.

Pollock, M. R. \& Torriani, A.-M. (1953). Purification and characteristics (physico-chemical) of the penicillinase of Bacillus cereus. Compte rendu hebdomadaire des séances de l'Académie des sciences, Paris 237, 276-278.

Rolinson, G. N. \& Sutherl.AND, R. (1968). Carbenicillin, a new semisynthetic penicillin active against Pseudomonas aeruginosa. Antimicrobial Agents and Chemotherapy-1967, 609-613.

SABATH, L. D. (1968). Synergy of antibacterial substances by apparently known mechanisms. Antimicrobial Agents and Chemotherapy-1967, 210-217.

Sabath, L. D., JAGo, M. \& Abraham, E. P. (1965). Cephalosporinase and penicillinase activities of a $\beta$ lactamase from Pseudomonas pyocyanea. Biochemical Journal 96, 739-752.

Sawai, T., Mitsuhashi, S. \& Yamagishi, S. (I968). Drug resistance of enteric bacteria. XIV. Comparison of $\beta$-lactamases in Gram-negative rod bacteria resistant to $\alpha$-amino benzyl penicillin. Japanese Journal of Microbiology 12, 423-434.

Smith, J. T. \& Hamilton-Miller, J. M. T. (I963). Differences between penicillinases from Gram-positive and Gram-negative bacteria. Nature, London 197, 976-978.

Smith, J. T., Hamilton-Miller, J. M. T. \& Knox, R. (I969). Bacterial resistance to penicillins and cephalosporins. Journal of Pharmacy and Pharmacology 21, 337-358.

SNEATH, P. H. A. \& Collins, J. F. (1961). A method for chromatographic detection of penicillins and related compounds and of penicillinase. Biochemical Journal 79, 5I2-5I4.

Stratford, B. C. (1968). The treatment of infection due to Pseudomonas aeruginosa with carbenicillin ('Pyopen'). The Medical Journal of Australia 2, 890-895.

SYKES, R. B. \& Richmond, M. H. (1970). Intergeneric transfer of a $\beta$-lactamase gene between Pseudomonas aeruginosa and Escherichia coli. Nature, London 226, 952-954. 